\title{
透明導電膜 最近の動向
}

\author{
水 橋 衞*1

\section{Recent Progress in the Transparent Conducting Oxide Thin Films Mamoru MIZUHASHI}

\author{
Graduate School of Science and Engineering, Aoyama Gakuin University, \\ 5-10-11 Fuchinobe, Sagamihara, Kanagawa 229-8558, Japan
}

(Received December 25, 2007, Accepted June 7, 2008)

\begin{abstract}
An overview on the recent progresses in transparent conducting oxide thin films of $\operatorname{In}_{2} \mathrm{O}_{3}, \mathrm{ZnO}$ and $\mathrm{TiO}_{2}$ concludes with a proposal that encourages the re-examination of the action and reaction of dopants with the host lattice in order to establish the deposition conditions that suppress the formation of undesirable defects in terms of carrier generation and mobility enhancement.
\end{abstract}

透明導電膜はマン・マシーン・インタフェースを担う表示 デバイスにとって必須の基礎材料であり, 液晶が台頭した 1970年以前を含めると60年以上にわたる長い開発の歴史を 有する.

\section{2000年頃までの開発の流れ}

金属材料, とくに高導電性の貴金属（金，銀，銅）では $10^{-6} \Omega \mathrm{cm}$ クラスの比抵抗と可視域〜赤外〜電波領域にわた り高い反射率を有する. 通常は透明な絶縁体である酸化スズ は1940年代に Sb 添加により導電性 $\left(10^{-3} \Omega \mathrm{cm}\right)$ になるこ とが発見され, 透明性が要求される空ガラス等への応用（赤 外線反射）が特許化された1).

1960年代末期, 液晶素子が黎明期を迎え, より抵抗の低 い透明材料の要求に応える形でスズを $2 \sim 10 \%$ 程度添加した 酸化インジウム（ITO）が登場し2,3)，比抵抗は 1 桁低い $10^{-4} \Omega \mathrm{cm}$ となった． 1980 年代の主要な液晶デバイスはワー プロであり，多くの文字を表示できる大面積化競争のため ITO 成膜業界は低抵抗化と大面積基板の安定供給を迫られ た. 業界努力の末1990年代に至り dc magnetron sputtering による生産方式が確立され, ITO の比抵抗は $2 \times 10^{-4} \Omega \mathrm{cm}$ と安定した. 90年代半ばから active matrix 駆動への切り替 わりが本格化し, ITO 基板を購入して a-Si TFT アレイを作 り液晶パネルを製造していたパネルメーカーは, 製造歩留を 上げるために ITO 成膜プロセスを TFT 製造工程に取り込 んだ. TFT 駆動の液晶ディスプレイは twist mode（電圧で 液晶の偏光状態を変える電圧素子) であるため各画素に電圧 がかかればよいので，1990年代まで20年にわたって続けら

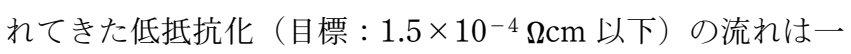
旦弱なった。

1990年代後半に入り有機 EL が脚光を浴び始める. EL は 発光輝度が電流密度に比例する電流素子であり, 再び低抵抗 化が要求され, 加えて, 表面平坦化技術が必須となった. $\mathrm{EL}$ 発光層の厚みは $200 \mathrm{~nm}$ 程度しかないため ITO に $10 \mathrm{~nm}$ 程度の表面凹凸があれば先端放電により素子が損傷する可能

*1 青山学院大学大学院理工学部 (神奈川県相模原市淵野辺 5-1011)
性が高まる，表面凹凸を EL 層厚の $1 / 10$ 以下にする試みと して ZnOによる下地処理が有効なことが判明した4)。この $\mathrm{ZnO}$ 膜は通常の核成長制御に用いられる $10 \mathrm{~nm}$ 程度の厚み ではなく $200 \mathrm{~nm}$ と厚い. しかし下地処理は製造工程を増や しコスト高になるため, 導電膜のアモルファス化, 微結晶化 が研究され, $\mathrm{In}_{2} \mathrm{O}_{3}$ に亜鉛を加えた IZO 膜の登場となった. IZO は導電性の点で ITO にやや劣る $\left(3 \times 10^{-4} \Omega \mathrm{cm}\right.$ 程度 $)$ が基板温度を低くして, いわゆるアモルファス化しても導電 性低下が少ない特徵もある. 低抵抗化の極限への挑戦では, 安定化ジルコニヤ結晶基板上に PLD (pulsed Laser deposition）法で成膜することで $7 \times 10^{-5} \Omega \mathrm{cm}$ という高い導電性 が安定的に得られることが明らかにされた ${ }^{5-7)}$.

2002 年は PDP 元年と称されるが，PDP 開発は1960年代 イリノイ大学で始まった. ガスの発光現象であるためモノク ロ表示しかできないと, 米国での開発は途絶えた. その後, 富土通と広島大学が地道にカラー化開発を続けた結果, 大画 面表示デバイスとして復活した. PDP の各表示セルの断面 はガラス基板側から透明導電膜, 絶縁層, 酸化マグネシウム 膜の積層構造となっている. 当初, 絶縁層には $\mathrm{PbO}$ を含む ガラスフリットが使われたが，フリットを $500^{\circ} \mathrm{C} て ゙$ 熱処理し てガラス化する際にガラスに侵食されにくい透明導電膜が必 要であったため, 化学的に安定な酸化スズが使われた. しか し, 酸化スズは安定な分, エッチングによる微細なパターン 形成が難しく, ITOへの切り替え進められた結果として, フリットの組成改良が奏功し1990年代から ITO になった。 さらに PDP は駆動電圧が $200 \mathrm{~V}$ 程度あるため健康 ·安全の 観点から電磁波漏洩が問題視されたため表示パネル前面に反 射防止したITO, あるいは銀膜を高屈折率誘電体で挟んだ 高透過率電磁シールドが装着されている.なお，ごく最近は 金属細線を挟んだグリッドワイヤタイプも多用されている.

上記の特性面での改善のほかに, 成膜プロセスの低温化の 流れがある. 時間短縮, 安全性向上によるコスト削減を可能 にするので重要な開発項目となっている.

現時点で透明性 · 導電性 ·微細加工性 ·化学的安定性いず れの点についても ITO を凌駕する材料はない. ITO は真に 優れた材料であるが，鉛を含むハンダの衰退に伴いその主原 料たる亜鉛採掘が減少し，2006年に至り亜鉛の副生物であ 
るInの高騰が始まった. In は元々希少資源であるから，よ り高機能な半導体 InSb や GaInAs 用に温存すべく， 1980年 代から $\mathrm{ZnO}$ 系を筆頭に代替材料の探索が行なわれてきた が，ここにきて新たに $\mathrm{TiO}_{2}$ が加わった ${ }^{8,9)}$.

$\mathrm{ZnO}$ 膜のドーパントの主流は周期表右隣の $\mathrm{Al}$ であり, 添 加量は $2 \sim 3 \%$ である. $\mathrm{AZO}$ 膜の比抵抗は基板を $200 \sim 300^{\circ} \mathrm{C}$ 程度に加熱した $\mathrm{dc}$ スパッタで $3 \times 10^{-4} \Omega \mathrm{cm}$ 程度が得られる が，膜厚 $400 \mathrm{~nm}$ 以上の厚膜の場合の結果である. $200 \mathrm{~nm}$ 以下の膜厚の薄い領域で比抵抗が数倍に急増してしまうこと, $\mathrm{ZnO}$ が弱酸に対してすら非常に容易に侵食されることが液 晶分野への販路が開けない大きなネックになっている.しか し, 膜が厚くてもシート抵抗が低ければよく，かつ，厚膜で 生じる表面凹凸は光閉じ込めの観点からむしろ歓迎される太 陽電池用には大いに期待されており，太陽電池向け表面形状 の最適化や成膜速度の向上が研究開発の対象となってい る10). また, ドーパントとしては $\mathrm{Al}$ 以外に $\mathrm{B}, \mathrm{Ga}$ を添加し た BZO · GZO 膜も検討されている ${ }^{11-14)}$. 低抵抗化視点から いえば，PLD (pulsed Laser deposition) 法で2003年に GZO 膜で $10^{-5} \Omega \mathrm{cm}$ にまで到達した ${ }^{13)}$. $200 \mathrm{~nm}$ 以下の膜厚領域 でITO と同レベルになる可能性の追求が続いている.

本特集で採り上げられている意外な導電材料 $\mathrm{TiO}_{2}$ は 5 価 の $\mathrm{Nb}$ をドープすることで得られるアナターゼ結晶膜であ る.しかしながら, 高い導電性 $\left(2.5 \times 10^{-4} \Omega \mathrm{cm}\right)$ を示すの は $\mathrm{SrTiO}_{3}$ 単結晶基板上へ PLD 法でエピタキシャル成長さ せた場合 ${ }^{15)}$ に限られている. ガラス基板では常温成膜後の 還元熱処理で $6 \times 10^{-4} \Omega \mathrm{cm}$ が得られている16). 化学的な安 定性にきわめて優れ，かつ，Inに比べると資源的な問題も 全くないので, 導電性発現のメカニズム研究, およびガラス のような基板であっても通用する技術開発につながる研究が 進められている.

\section{2. 導電性の改善の視点}

電気伝導度は $\sigma=n_{e} e \mu$ であるから, 移動度 $\mu$ を高くするこ と, キャリヤ密度 $n_{e}$ を高めることが導電性の改善に寄与す る.

\section{1 移動度}

移動度 $\mu$ と平均自由行程 $l$ との関係は ITO 膜では大まか に

$$
l=0.14 \mu
$$

である．単位は $l[\mathrm{~nm}], \mu\left[\mathrm{cm}^{2} / \mathrm{Vs}\right]$. 係数 0.14 はどのタイプ の散乱中心からの寄与が主体であるかに依存する。導電性の 高いITOの場合にはイオン化不純物散乱が優勢であるか ら，そのような場合の係数が 0.14 と理解すればよい。

散乱中心のタイプを識別できる場合の移動度は

$$
1 / \mu=1 / \mu_{1}+1 / \mu_{2}+1 / \mu_{3}+1 / \mu_{4}+\cdots
$$

で与えられる. 散乱中心として, 正しく帯電した格子点上の 不純物イオン, 格子点以外の場所を占める中性不純物原子あ るいはその集合体であるクラスタ，酸素欠陥など負帯電した イオン，格子点の熱振動であるフォノン，その他成膜中に膜 に取り达まれたガス分子, 水分子などの意図しない不純物, 更には粒界や表面がある。電子輸送の一般論は文献17)に詳 しい.キャリヤ散乱を区別して議論する場合の知識としては
以下のような文献がある. 不純物散乱機構全体 : ${ }^{18)}$, 中性不 純物散乱: ${ }^{19,20)}$, イオン化不純物散乱: ${ }^{21-23)}$ など古いもので あるが重要である。（2)式から, 移動度を小さくするような 優勢な散乱プロセスが移動度を決めると言うことができる が，拮抗しているプロセスがいくつかあれば事情はかなり異 ったものになり，いろいろな改良改善の余地がでてくる.

キャリヤ密度の高いITO 膜ではイオン化不純物散乱が支 配的であることが定説になっているが，低温形成 ITO やア モルファス IZO になれば各散乱機構の寄与が異なってくる はずである、これら ITO, IZO 膜, あるいは新しいドーパン トを導入した $\operatorname{In}_{2} \mathrm{O}_{3}$ 膜 $\left.24-29\right)$ に関する散乱機構の議論はまだ殆 どなく, 今後の解明に期待したい。さらに, キャリヤを生成 しないが散乱中心にはなりえる構造欠陥型散乱中心（中性不 純物, ボイド, 転位, 粒界など) についても, どれかが優勢 な状況をつくり，それらの寄与を明らかにすることも材料物 性の基本的理解のうえで重要である.

ごく最近になって, デバイス応用の観点から ITO 膜の移 動度を高める目的の研究が見られれるようになってき た ${ }^{29)}$. フラットパネルディスプレイに留まらず太陽電池, EL, LED, ウェーブガイドなどの領域では今まで以上に透 明であること, あるいは高い耐熱性25)が意味を持つと考え られ始めている．前者では自由電子吸収が可視域に影響しな いようキャリヤ密度を低めに抑え, 移動度を稼ぐことで導電 性を高めることが研究の目的である．移動度を高めるのに必 要なことは多結晶体としての結晶性の良質を損なわない組成 や構造をつくることで, この部分の解明が次世代透明導電膜 につながる基盤技術となるであろうことは疑いない。

\section{2 キャリヤ密度}

電流を運ぶのは化学結合の形成に使われていない自由電子 であり, ITO 材料開発史的に言えば $6 \times 10^{20} \mathrm{~cm}^{3}$ から倍増し て現在の高導電性 ITO で $(1.2 \sim 1.3) \times 10^{21} \mathrm{~cm}^{3}$ となってい る.

自由電子の起源は, $\mathrm{In}_{2} \mathrm{O}_{3}$ に $\mathrm{Sn}$ 原子をドープすることで $\mathrm{Sn}^{4+}$ が格子点の $\mathrm{In}^{3+}$ に置換するときに余剰になる 1 ケの電 子であるが, $\mathrm{In}_{2} \mathrm{O}_{3}$ は酸素のない雾囲気で $300 \sim 400^{\circ} \mathrm{C}$ 程度の 比較的低温で処理するだけで，つまり Sn 添加なしでも $10^{-3}$ $\Omega \mathrm{cm}$ 程度の比抵抗となることも知られている. 即ち酸素空 孔も自由電子生成にかなり寄与して抢り ${ }^{30)}$, 酸素分圧々 Sn 添加量を変数にしてキャリヤ密度を算出するモデル化も行な われている31). また，よく知られたことであるが，2\%以上 のドープになると加えたもの全てが格子点の $\mathrm{In}^{3+}$ を置換し 最大原子価に正しくイオン化して自由電子を放出するわけで なく，無駄になってどこかの片隅に存在している32).

しかしここで大切な前提があることを忘れてはならない. すなわち, かなりのドープレベルまで母体の $\mathrm{In}_{2} \mathrm{O}_{3}$ の結晶構 造が良い状態で維持されているという前提である. $300^{\circ} \mathrm{C}$ 以 上の高温成膜が低抵抗 ITO を得やすいのは飛来原子や分子 の表面移動度が大きいからであり，やや低温基板であっても 成膜速度の遅い PLD 法を使うと $10^{-5} \Omega \mathrm{cm}$ 台の比抵抗が得 られるのも同じ理由で当然といえる. ITO 薄膜の場合, 基 板温度が $300^{\circ} \mathrm{C}$ もれば膜厚が $50 \mathrm{~nm}$ 以下でも鋭い回折線が 得られる.これは薄膜成長の初期段階で良質な微結晶がで 
き, 微結晶同土が互いにスムースに繋がっていることを表わ しており， $\mathrm{In}_{2} \mathrm{O}_{3}$ の単位胞 (Unit Cell) が $\mathrm{Sn}$ 不純物のよう な異物の存在に対して多少の内部变形を許して柔軟に振舞え るだけの十分な空間を擁していることがその背景にあるので はないかとの想像を掻き立てる33)。このあたりの詳細な構 造解析はまだこれからという状態である。他方, $\mathrm{ZnO}$ 或い は $\mathrm{ZnO}: \mathrm{Al}$ 膜の場合, この程度の薄い膜での結晶性はよく ない. 厚膜で低抵抗化する理由のひとつに微結晶生成メカニ ズムの違いが指摘されている34,35).

一方で，せっかくできた自由電子が捕獲されるメカニズム も存在する筈で, 測定にかかる自由電子密度は, 生成された 電子から捕獲された電子を除いたものということになる。ど こかの片隅にあるものが $\mathrm{Sn}^{2+}$ や $\mathrm{Sn}^{3+}$ ，更には膜表面や空 隙に吸着した酸素や水分子であればこれらがイオン化して電 子を捕獲したとしても何の不思議もない.

\section{3. まと め}

以上述べてきたことから分かるように，ITOの場合イオ ン化不純物散乱を通じてキャリヤの移動を阻害する要因にキ ヤリヤ自身が深く関わる関係になっているため，これらを独 立に最適化することはできない。この視点に立って展開方向 を探ると以下のようになると考える。

導電性を高める点に着目する場合, 要因は良好な結晶性を 維持すること，キャリヤを捕捉するような構造欠陥をつくら ないことであり，そのためには(1)成膜プロセスによる構造欠 陥生成を抑制する配慮（あるいは，成膜方法選択の見直し）, (2)不純物の種類およびその必要最小限のドーピングレベルを 改めて精査（構造歪最小化, 粒界析出物を最小化して移動度 の最大化を図る)，(3)その中から望ましい物性を示す光吸収 の少ないものを選ぶということであろう.

とはいえ，上記の判断に至る知識はまだITOですら不十 分である. また，他材料で今後さらに議論を深めるべきとこ ろは，ZnOではイオン化不純物散乱のほかに薄い膜段階か ら良質な結晶を得る手段・方法や粒界散乱の影響, $\mathrm{TiO}_{2}$ ： $\mathrm{Nb}$ ではフォノン散乱の影響を定量的に把握することであ る.さらに電子デバイス分野では良質な界面親和性設計のた めの基礎データ（フェルミレベルの位置, 真空準位位置, 拡 散長など）蓄積が望まれるところである.

\section{[文献]}

1）USP2, 429, 420（出願 Oct. 5, 1942）および 2, 564, 706 (May $2,1946)$.

2) H. J. J. van Boort and R. Groth: Philips Tech. Rev., 29 (1968) 17.

3) D. B Fraser and H. D. Cook: J. Electrochem. Soc., 119 (1972) 1368 .
4) C. H. Yi, I, Yasui and Y. Shigesato: Jap. J. Appl. Phys., 34 (1995) 1638.

5) N. Taga, H. Odaka, Y. Shigesato, I. Yasui and T. E. Haynes: J. Appl. Phys., 80 (1996) 978.

6) H. Ohta, M, Orita, M. Hirano, H. Tanji, H. Kawazoe and H. Hosono: Appl. Phys. Lett., 76 (2000) 2740.

7) H. Ohta, M, Orita, M. Hirano and H. Hosono: J. Appl. Phys., 96 (2002) 3547.

8) Y. Furubayashi, T. Hitosugi, Y. Yamamoto, K. Inaba, G. Kinoda, Y. Hirose, T. Shimada and T. Hasegawa: Appl. Phys. Lett., 86 (2005) 252101.

9) Y. Furubayashi, T. Hitosugi, Y. Yamamoto, Y. Hirose, M. Ohtani, K. Nakajima, T. Cjikyow, T. Shimada and T. Hasegawa: Mater. Res. Soc. Symposium Proc., 905E (2006) 0905-DD0201.1 .

10) C. Agashe, O. Kluth, G. Schöpe, H. Siekmann, J. Hüpkes and B. Rech: Thin Solid Films, 442 (2003) 167.

11) H. Ogura, A. Suzuki, T. Matsusita, T. Aoki and M. Okuda: Thin Solid Films, 445 (2003) 263

12) T. Nakada, Y. Ohkubo, N. Murakami and A. Kunioka: Jap. J. Appl. Phys., 34 (1995) 3623.

13) T. Minami, H. Nanto and S. Takada: Jap. J. Appl. Phys., 24 (1985) 781.

14）宋豊根, 重里有三，月刊マテリアルインテグレーション, 1999年12月号, pp. 15.

15）古林 寛, 一杉太郎, 山本幸生, 廣瀬 靖, 稲葉和久, 木野 田剛, 島田敏宏, 長谷川哲也, 寺嶋孝仁, 高野幹夫, 学振第 166 委員会第30回研究会資料（2005年 1 月 27 日） pp. 47.

16） http://www.chem.s.u-tokyo.ac.jp/users/sschem/haselab/

17）アシュクロフト・マーミン，固体物理の基礎，16章および26 章, 吉岡書店, 物理学叢書 (1982).

18) E. Conwell and V. F. Weisskopf: Phys. Rev., 77 (1950) 388.

19) C. Erginsoy: Phys. Rev., 79 (1950) 1013

20) T. C. McGill and R. Baron: Phys. Rev., B11 (1975) 5208.

21）W. ショックレイ, 半導体物理学, 11章, 吉岡書店（1963）.

22) R. B. Dingle: Phil. Mag., 46 (1955) 831.

23） P. Große, 電子物性の基礎, 6 章, 金原粲監修, 水橋衞訳, オーム社（1993）。

24) Y. Shigesato, N. Shin, M. Kamei, P. K. Song and I. Yasui: Jap. J. Appl. Phys, 39 (2000) 6422.

25) T. Asikainen, M. Ritala and M. Leskla: Thin Solid Films, 440 (2003) 152

26) P. K. Song, Y. Shimada, Y. Shigesato, T. Hattori, M. Ishida and K. Saegusa: Thin Solid Films, 442 (2003) 184.

27) S. Y. Sun and J.-L. Huang: J. Matr. Res., 20 (2005) 247.

28) B. Yaglioglu, Y.-J. Huang, H.-Y. Yeom and D. C. Paine: Thin Solid Films, 496 (2006) 89

29) M. F. A. M. van Hest, M. S. Dabney, J. D. Perkins and D. S. Ginley: Thin Solid Films, 496 (2006) 70.

30) M. Mizuhashi: Thin Solid Films, 76 (1981) 97.

31) G. Frank and H. Köstlin: Appl. Phys., A27 (1982) 197.

32) Y. Shigesato and D. C. Paine: J. Appl. Phys., 73 (1993) 3805

33) F. Utsuno, H. Inoue, I. Yasui, Y. Shimane, S. Tomai, S. Matsuzaki, K. Inoue, I. Hirosawa, M. Sato and T. Honma: Thin Solid Films, 496 (2006) 95.

34) J.-H. Lee and B.-O. Park: Thin Solid Films, 426 (2003) 94

35) I. Petrov, V. Orlinov and A. Misius: Thin Solid Films, 120 (1984) 55. 